\title{
THE EFFECTIVENESS OF FINGERHOLD RELAXATION TECHNIQUE AND SPIRITUAL EMOSIONAL FREEDOM TECHNIQUE (SEFT) TO THE PAIN INTENSITY SCALE ON PATIENTS WITH POST CAESAREAN SECTION
}

\author{
Atun Raudotul Ma'rifah ${ }^{1}$, Rahmaya Nova Handayani ${ }^{2}$, Pramesti Dewi $^{3}$ \\ ${ }^{1,2,3}$ STIKes Harapan Bangsa Purwokerto \\ Correspondence: atunraudotulmarifah@gmail.com, mayanova2005@gmail.com,pramestidshb@gmail.com
}

\begin{abstract}
Post caesarian section pain can cause physical and psychological effects to mothers. The pain can be reduced with pharmacological or non-pharmacological pain management. One of the pharmacological techniques is fingerhold relaxation and spiritual emotional freedom technique (SEFT). The study aimed to discover the effectiveness of fingerhold relaxation and SEFT to pain intensity of post caesarean section. This study was categorized into quasi-experiment research with two groups comparison pre-test and post-test design. The samples were 45 respondents comprising of 15 respondents for experimental group using SEFT, 15 for experimental group using fingerhold relaxation, and 15 for control group. The data was analyzed using regression linier test. The result showed that the correlation value of control group was 0,431 with R-Squere $18,6 \%$. Meanwhile, in experimental group with fingerhold relaxation, the correlation value was 0.671 and Rsquare value was $45 \%$. Furthermore, the correlation value of experimental groups using SEFT was 0.874 and $\mathrm{R}$ square was $76 \%$. In conclusion, SEFT is effective to decrease the pain on patient with post caesarean section. Therefore, nurses are required to help mothers to feel comfortable in controlling the pain of post caesarean section.
\end{abstract}

Keywords: caesarean section, finggerhold, pain, SEFT

\section{INTRODUCTION}

Caesarean section is the birth of fetus through the abdominal and requiring incision into the uterus (hysterotomy) (Norwitz, 2007). The developmet of caesarean section operation in Indonesia based on the simple survey conducted by Gulardi and Basalamah towards 64 hospitals in Jakarta in 1993, the result presented that $35,7-55,3 \%$ of 17.665 births were done through caesarean section operation (Kasdu, 2009). The pain of post operation will cause physical and psychological reactions to mothers with postpartum such as impaired mobility, less likely to have activities, insomnia, loss of appetite, baby blues in order that there should be a technique to control the pain to make them adaptable with the pain of caesarean section post operation and to fasten masa nifas (Bobak et al, 2004 in Miranti, 2011). 
Uncomfort or pain must be overcomed becaust comfort is the human basic need as stated in Maslow's hierarchy. The pain will affect to the daily activities and the sleep of someone (Potter \& Perry, 2006).

Pain management has several interventions or a procedure either pharmacology or non-pharmacology. The pharmacolgical procedure is conducted by giving analgesic - to decrease or to heal the pain (Potter \& Perry, 2010). Whereas, non-pharmacological one is done through relaxation, breathing technique, position mobile, massage, acupressure, hot/cold therapy, hypnobirthing, music, and Transcutaneous Electrical Nerve Stimulation (TENS) (Yuliatun, 2008).

One of pharmacological treatments that can be used is fingerhold relaxation technique. It is easy technique to control emotion. The emosion likes energy wave which moves through our body, thought, and soul.

According to a study on the implementation of fingerhold relaxation technique firstly conducted by Pinandita (2011) entitled "The effectiveness of fingerhold relaxation technique to the decrease of pain intensity on patient with laparatomi post operation", the result shows that $\mathrm{p}$-value of $\mathrm{t}$-independent test is $0.000(\mathrm{p}<0,05)$ - meaning that there is an effect of fingerhold relaxation technique towards the decrease of pain intensity on patients with laparatomy operation.

SEFT therapy is technique combining body energy system (energy medicine) and spiritual therapy using tapping methode on some certain spots on the body, SEFT has been proven to overcome physical and psychological (Faiz, 2008).

Fajar's study on the effectiveness of spiritual emosionl freedom technique to the decrease of pain level at Tugurejo Regional Public Hospital of Semarang shows that the result of SEFT therapy is effective to decrease the pain on mothers with caesarean section 
Atun Raudotul : The Effectiveness of Fingerhold Relaxation Technique

post operation. The research recommends that SEFT therapy can be used as an independent nursing to decrease pain (Fajar, 2010)

Rajin's study, 2010, SEFT therapy to increase the sleeping quality on post-operation patients at hospital shows that SEFT therapy can increase patients' sleeping quality significantly.

Prof. Margono Soekardjo Regional Public Hospital is a referral hospital which almost 100 patients/month conduct section caesareans operation with various indication. To overcome the pain of post operation, pharmacological therapy is still used to handle pain of post operation where there is only pharmacological therapy and the procedure operational standard of non-pharacological therapy has not been available yet. Fingerhold technique is easy and low cost methode as well as SEFT that can be done by every patient in five minutes. The objective of this study is to identify the effectivess differences of fingerhold relaxation and SEFT to decrease client's pain of caesarean section post operation.

\section{METHODS}

The study is quasi experiment research with pre- and post test design with control group design yaitu observasi conducted twice: before and after the treatment suing control group. Pre- and post test with control group design was used to investigate the effectiveness of the treatment through the difference between experimental and control groups (Arikunto, 2009). This study would examine two variables, they are: dependent variable of this study was pain intensity of caesarean section post operation and independent variable was fingerhold relaxation technique and SEFT.

The population in this study were mothers with caesaren section post operation at Prof. Margono Soekardjo Regional Public Hospital. Sampling technique was purposive sampling to determine the sample in accordance with the researcher (Setiadi, 2007). Inclusion 
Atun Raudotul : The Effectiveness of Fingerhold Relaxation Technique

criteria of mothers with caesarean section post operation in the first day withouth complication such as miocardiac infarction or diabetes militus. The number of sample was determined by the formula of the amount of sample o experimental research or clinical test. As the consequence, there were 45 respondents as the sample which would be divided into three groups: first group with fingerhold treatment, second group with SEFT treatment, and the last group being control group.

Data gathered would be analized through statistical test using a computer. Data analysis methode used in this study were univariat and bivaariat analysis. The following are the analysis types used (1) Univariate analysis was used to get a description of each variable. It includes mean, mode, meidan and maximal, diviasion standard and proportion characteristic as well as the variable of pain level in each measurement either pre-test or posttest; and (2) Bivariat Analysis to recognoze the difference of pain level on control group, intervention 1, and intervention 2, paired-t test was used for normal data distribution and Wilcoxon was for abnormal data. To know the difference of pain level between control group and group with intervention 1 and intervention 2, One Way Annova was used for normal data and Kruskal Wallis Test was for abnormal data. After applying different test with more than two samples, it would be more effective to continue the analysis using Poshoc test. 


\section{RESULTS}

Table 1. The Difference of Pain Level of Caesarean Section Post Operation Before and After Implemented with SEFT

\begin{tabular}{lcccc}
\hline \multicolumn{1}{c}{ Variable } & $\mathrm{N}$ & Mean & $\mathrm{Z}$ & $p$-value \\
\hline $\begin{array}{l}\text { Before in } \\
\text { experimental } \\
\text { groun with }\end{array}$ & 15 & 6.4 & 3.391 & 0.01 \\
SEFT & & & & \\
\hline $\begin{array}{l}\text { After in } \\
\text { experimental } \\
\text { group with }\end{array}$ & 15 & 4.07 & & \\
SEFT & & & & \\
\hline
\end{tabular}

Based on the Table 1., the result of $p$ value is $0.01(p<\alpha)$, it means that there is a significant different of pain scale before and after implemented with SEFT in experimental group with the average difference of the pain decrease is 2.23 .

Table 2 The pain Level Difference of Caesarean Section Post Operation Before and After Implemented with Fingerhold Relaxation

\begin{tabular}{lcccc}
\hline Variable & $\mathrm{N}$ & Mean & $\mathrm{Z}$ & $\begin{array}{c}p \\
\text { value }\end{array}$ \\
\hline $\begin{array}{l}\text { Before in } \\
\text { fingerhold } \\
\text { group }\end{array}$ & 15 & 4.67 & -3.416 & 0.001 \\
$\begin{array}{l}\text { After in } \\
\text { fingerhold } \\
\text { group }\end{array}$ & 15 & 3.13 & & \\
\hline
\end{tabular}

Based on the Table 2., the result of $p$ value is $0.001(p<\alpha)$, it means that there is a significant different of pain scale before and after implemented with SEFT in experimental group with the average difference of the pain decrease is 1.54 . 
Table 3. The Pain Level Difference of Caesarean Setion Post Operation in Control Group

\begin{tabular}{lcccc}
\hline \multicolumn{1}{c}{ Variable } & $\mathrm{N}$ & $\begin{array}{c}\text { Mean } \\
\text { rank }\end{array}$ & $\mathrm{Z}$ & $\begin{array}{c}p \\
\text { value }\end{array}$ \\
\cline { 1 - 3 } $\begin{array}{l}\text { Before in } \\
\text { control group }\end{array}$ & 15 & 4.53 & -2.889 & 0.004 \\
\cline { 1 - 2 } $\begin{array}{l}\text { After in cotrol } \\
\text { group }\end{array}$ & 15 & 3.60 & & \\
\hline
\end{tabular}

Based on the Table 3., the result of $p$ value is $0.004(p<\alpha)$, it means that there is a significant different of pain scale before and after in control group with the average difference of the pain decrease is 0.93 .

Table 4. The Pain Level Difference of Caesarean Section Post Operation between Experimental and Control Groups

\begin{tabular}{|c|c|c|c|}
\hline Pain & $F$ & $R$ & $\begin{array}{c}R- \\
\text { square }\end{array}$ \\
\hline Control Group & 2.971 & 0.431 & 0.186 \\
\hline $\begin{array}{l}\text { Fingerhold } \\
\text { Group }\end{array}$ & 28.930 & 0.671 & 0.450 \\
\hline SEFT Group & 41.929 & 0.874 & 0.763 \\
\hline
\end{tabular}

Based on Table 4., it can be seen that the control group with correlational value was 0.431 with $18.6 \%$ of R-Square indicating that the treatment control group only can affect the pain about $18.6 \%$. While the correlational value of experimental groups with fingerhold relaxation was 0.671 with $45 \%$ of R-Square and the correlational value of experimental group with SEFT was 0.874 with $76 \%$ of R Square.

In conclusion, SEFT has more effectiveness value in decreasing pain of post operation than fingerhold therapy as well as in control group. 


\section{DISCUSSION}

The effect of Fingerhold Relaxation Technique on the Decrease of Caesarean Section Post Operation Pain at Prof. Margono Soekardjo Regional Public Hospital

Relaxation is one of ways to decrease pain or to prevent the presence of pain by decreasing muscle tention. It is an effort to minimize the pain stimulation by resting or relaxing body muscles. This technique is easy to be learnt by mothers with post-partum. They just breath in deeply with regular breathing pattern and relax, releasing endorphin in the body or relaxing naturally in the body with normal condition. (Hidayat dan Uliyah, 2008).

The decrease of pain mostly happened on experimental group rather than on control group. This is in line with the theory of Gate Control from Melzack and Wall (1965) in Potter \& Perry (2006) who suggested that pain impulse can be cotroled or even blocked by defence mechanism along the cetral nerve system. This theory states that pain impulse delivered when the defenseis opened an impulse is blocked when the defense is closed. The efforts to closed the defense are the theoretical foundation to loss the pain. The Blockage is done through distracting attention or doing relaxation.

Handling pain with non-pharmacological technique is the main asset to reach comfortableness (Yusrizal, 2012). The use of non-pharmacological management is more low cost and withouth side effect than pharmacological management.

In experimental group, the respondents were treated with fingerhold relaxation therapy fro \pm 30 menutes. The result of the study showed that pain scale after the treatment was lower than those withouth the fingerhold relaxation technique. This aimed to make them relax and to decrease their pain scale. Meanwhile, in the control group the respondent did not get fingerhold relaxation technique in order that there was no the decrease of pain scale because of no stimulation. 
Fingerhold relaxation technique is an easy way to manage emotion and to develop emotional intelligence (Cane, 2013) and Potter and Perry (2006) stated that relaxation technique enabled patients to control theslves when they felt uncomfortable or painful, physical stress and emotion because of pain.

In line with study of Pinandita (2012) with the title of "The Effectiveness of Fingerhld Relaxation Technique towards the Decrease of Pain Intensity on Patients with Laparatomy Post Operation", the result showed that there was an effect between fingerhold relaxation technique to the decrease of pain intensity on laparotomy post operation patients with $p$ value $0,000(p<\alpha)$. In conclusion, the fingerhold relaxation technique is one of was to decrease pain on patients with xcaesarean section post operation.

\section{The effect of Spiritual Emosional Freedom Tehnique (SEFT) Therapy on the Decrease of Caesarean Section Post Operation Pain at Prof. Margono Soekardjo Regional Public}

\section{Hospital}

Intervention with SEFT was proven to be effective in decreasing the pain scale intensity of caesarean section post operation. It could be seen from the result of pain intensity decrease in group with SEFT intervention. Spirituality was an important aspect and the highest because this was related to transcendent with God, it would guide and gave meaningful life purpose of someone (Mauk \& Schimdt, 2004). Spriritual aspect of the subjects wasd touched through guiding them to utter sencere and resigned sentence which finally guided them in surrendered condition. This condition was the same as mediative condition that influenced physiological change of someone. Mothers would experience the decrease of heart rate frequency, the breathing becoming soft, decreasing metabolism, and increasing perifer blood circulation. Furtherore, it caused psychological effects such as selfesteem, optimism, calm and peaceful (Jantos \& Kiat, 2007; Breslin \& Lewis, 2008). The 
Atun Raudotul : The Effectiveness of Fingerhold Relaxation Technique

comlness effect could be seen mostly when the subjects were given with the intervention, they looked more ecalm in responding the pain of caesarean section post operation, their face and body muscles seemd more relax in order to decrease or even disappear.

Moreover, SEFT intervention also combines psychological energy technique in the form of tapping on 18 main meridian spots. Tapping will likely influence central nerve system. According to gate control theory, if the central brain has high activity, the gate in the spinal cord will close in order tah the sensation of pain will not reach to the brain centerand will not be interpreted as pain. Tapping or light hitting can stimulate acupoint in order to release internal opioids (endorphins, enchepalins and dynorphins) (Ulett, 1992 in Lane, 2009). It is also claimed as external stimulation which can disturb pain impulse delivery to brain center, so pain impulse sent to the brain is getting less.

Performing SEFT therapy, either emotional or physical problems experienced by someone like pain of caesarean setion post operation will decrease, or even disappears immediately. The reason is that SEFT emphasize more on spiritual element (pray) and body energy system using tapping methode on several certain spots in the body. Moreover, there is also relaxation methode involving belief factor of patient that enable to decrease the pain (zakiyyah, 2010).

This study qualitatively informs that pain will not disappear by itself, but patients will be more tolerant to the pain and report that their pain runs out faster even though there is caesarean section post operation injury left. It is in line with the statement of Dezutter et al. (2011) stating that praying has a meaning on painful tolerant of someone. Yuniarsih's study in 2012 is also stated that SEFT can decrease pain level on mothers of one-scale maternal as well as the study conducted by Wijiyanti (2010). 


\section{The effectiveness differences of fingerhold relaxation technique and SEFT to the pain} intensity scale on patients with caesarean section post operation at Margono Soekardjo Hospital - Purwokerto

In conclusion, spiritual emosional freedom technique has better value of effectiveness to decrease the pain of post operation than fingerhold technique as well as control group. It was $76 \%$ in SEFT group, while that in fingerhold relaxation technique group was $45 \%$ and in control group was $18.6 \%$.

In control group there was a decrease of pain though non-pharmacological therapy had not been implemented yet - fingerhold relaxation or SEFT because patient had still got analgesic medicine in the form of ketorolac. Instead of getting medicine, the respondents in experimental group were given non-pharmacology. The result showed that SEFT was effective to decrease the pain significantly. It is because SEFT therapy combined spiritual science, showing resigned and surrendered attitude of patients towards the illness they have, and it was accompanied with tapping on acupressure spots in order to make patients relax and lack of feeling painful.

SEFT intervention requisted that healthcare provider should be next to the client in order to give direct care to overcome the pain. As the consequence, it gave calmness automatically to the subject in order to handle the fraith of being alone and powerless could be solved. Brattberg (2008) and William \& Carey (2003) stated that resigned and surrendered sentences uttered repeatedly would be affirmative sentence that caused someone relax. Accordingly, it affected the increase of energy, minized fatigue, decreased stress hormone in order that the pain would decrease. 


\section{CONCLUSION}

The result of this study shows that the SEFT intervention can give positive impacts in decreasing the pain of section caesaria post operation. There is a significant difference on the decrease of average pain between experimental and control groups. The result of this study presents that SEFT including tapping is really effective in decreasing the pain of SC post operation. The study recommends that SEFT therapy can be used as an independent nursing intervention to overcome pain.

\section{ACKNOWLEDGEMENT}

1. The honorable Directorate of Higher Eduation that has founded during the process of this research through the program hibah penelitian Dosen Pemula

2. STIKES Harapan Bangsa Purwokerto

3. Prof. Margono Soekardjo Regional Public Hospital that has given permission to conduct the research

4. Anonames who support during this research

\section{REFERENCES}

Aini, LN. (2012). Pengaruh Latihan Ambulasi Terhadap Penurunan Intensitas Nyeri Pada Pasien Post Operasi Sectio Caesarea Di Ruang Anggrek RSUD Banyumas. Skripsi. Stikes Harapan Bangsa Purwokerto. Tidak dipublikasikan

Brattberg,G. (2008).Self Administered EFT (Emotional Freedom Techniques) in individuals with fibromyalgia: a randomized trial. Integrative Medicine, 7 (4), 30-35. Cane, PM. (2013). Hidup Sehat Dan Selaras: Penyembuhan Trauma. Alih Bahasa : Maria, S \& Emmy, L.D. Yogyakarta: Capacitar International, INC. 
Atun Raudotul : The Effectiveness of Fingerhold Relaxation Technique

Dahlan. (2011). Statistik Untuk Kedokteran Dan Kesehatan. Jakarta: Salemba.

Departemen Kesehatan RI. (2007). Profil Kesehatan Indonesia 2007. Jakarta: Depkes RI.

Dezutter,J., Wachholtz, A., \& Corveleyn, J. (2011). Prayer and pain: the

mediating role of positive re-appraisal. Journal behavior Medicine. Diunduh 19 Februari, 2013 dari http://www.kuleuven.be/thoma s/images/cms/Elisabeth/Dezutt er\%20Prayer\%20and\%20Pain. pdf.

Fraser, M. (2009). Buku Ajar Bidan. Edisi 14. Alih Bahasa: Sri Rahayu, Laili Mahmud. Jakarta: EGC.

Hidayat dan Uliyah. (2008). Ketrampilan Dasar Praktik Klinik untuk Kebidanan. Jakarta: Salemba Medika.

Hidayat, AA. (2008). Riset Keperawatan dan Teknik Penulisan Ilmiah. Jakarta: Salemba Medika.

Hidayat, AA, 2008. Pengantar konsep dasar Keperawatan, Jakarta. Salemba Medika. Indiarti, MT. (2007). Caesar Kenapa Tidak?. Yogyakarta: Almatera Publishing.

Kasdu, D. (2003). Operasi Caesar : Masalah dan Solusinya. Jakarta: Puspa Swara.

Kurniawati, D (dkk). 2009. Obgynacea obgyn dan ginekologi. Yogyakarta.Tosca

Kustanti, E. (2008). Pengaruh Teknik Relaksasi Terhadap Perubahan Status Mental Klien Skizofrenia Di Rumah Sakit Jiwa Daerah Surakarta. Diakses 29 Oktober 2013 dari 
Atun Raudotul : The Effectiveness of Fingerhold Relaxation Technique

http://publikasiilmiah.ums.ac.id/bitstream/handle/123456789/498/3f.pdf?sequenc $\mathrm{e}=1 \quad$ Jam $14.12 \mathrm{WIB}$

Liana, E. (2008). Teknik Relaksasi : Genggam Jari untuk Keseimbangan Emosi. Diakses 21 Oktober 2013 dari http://www.pembelajar.com/teknik-relaksasi-genggam-jariuntuk-keseimbangan-emosi Jam 08.22 WIB

Miranti , R. (2011). Pengaruh Pemberian Teknik Relaksasi Nafas Dalam Terhadap Perubahan Skala Nyeri Pada Ibu Primigravida Post Operasi Sectio Caesarea Hari 1 Di Ruang Flamboyan. Skripsi. Universitas Muhammadiyah Purwokerto. Tidak dipublikasikan

Norwitz, Errol dkk. (2007). At a Glance Obstetri \& Ginekologi Edisi 2. Jakarta: Erlangga.

Notoatmodjo, S. (2010). Metodologi nnnnnnnnnnnmPenelitian Kesehatan. Jakarta: PT Rineka Cipta.

Nurak, MT. (2011). Indikasi Persalinan Sectio Caesarea Berdasarkan Umur Dan Paritas Di Rumah Sakit DKT Gubeng Pojok Surabaya Tahun 2011. Diakses 23 Januari 2014 dari http://librarygriyahusada.com/library/images/files/Jurnal\%20Penelitian\%20Persalinan\%20Sec tio\%20Caesarea.PDF Jam 17.00 WIB

Nursalam. (2008). Konsep Dan Penerapan Metodologi Penelitian Ilmu Kesehatan Pedoman Skripsi, Tesis, dan Instrumen Penelitian Keperawatan. Jakarta: Salemba Medika. 
Atun Raudotul : The Effectiveness of Fingerhold Relaxation Technique

Patasik, CK. (2013). Efektifitas Teknik Relaksasi Nafas Dalam Dan Guided Imagery Terhadap Penurunan Nyeri Pada Pasien Post Operasi Sectio Caesare Di Irina D Blu Rsup Prof. Dr. R. D. Kandou Manado. Diakses 24 Oktober 2013 dari https://www.google.co.id/\#q=Efektifitas+Teknik+Relaksasi+Nafas+Dalam+Dan+ Guided+Imagery+Terhadap+Penurunan+Nyeri+Pada+Pasien+Post+Operasi+Sect io+Caesare+Di+Irina+D+Blu+Rsup+Prof.+Dr.+R.+D.+Kandou+Manado Jam 09.47 WIB

Pinandita, I. (2012). Pengaruh Teknik Relaksasi Genggam Jari Terhadap Penurunan Intensitas Nyeri Pada Pasien Post Operasi Laparatomi. Diakses 21 Oktober 2013 dari http://digilib.stikesmuhgombong.ac.id/files/disk1/27/jtstikesmuhgo-gdliinpinandi-1344-2-hal.32--3.pdf Jam 09.56 WIB

Potter \& Perry. (2006). Buku Ajar Fundamental Keperawatan Konsep, Proses Dan Praktik (ed.4, vol 2). Jakarta : EGC.

. (2010). Fundamental of Nursing Fundamental Keperawatan (buku 2 edisi 7). Jakarta: Salemba Medika.

. (2010). Fundamental of Nursing Fundamental Keperawatan. (buku 3 edisi 7). Jakarta: Salemba Medika.

Prasetyo, SN. (2010). Konsep Dan Proses Keperawatan Nyeri. Yogyakarta: Graha Ilmu. 
Atun Raudotul : The Effectiveness of Fingerhold Relaxation Technique

Puwahang. (2011). Jari-jari tangan. Diakses 29 Oktober 2013 dari http://titik-refleksi-padatangan Jam $12.44 \mathrm{WIB}$

Purwandari, A 2008. Konsep Kebidanan dan sejarah Profesionalisme.Jakarta.EGC

Ratnawati, dkk. (2011). Hubungan Antara Paritas Dan Nyeri Persalianan Pada Kala I Fase Aktif Di Bidan Praktik Swasta Enny Juniati Surabaya. Diakses 8 Februari 2014 dari http://suaraforikes.webs.com/volume2\%20nomor3.pdf Jam 09.00 WIB

Reeder et al. (2011). Keperawatan Maternitas Kesehatan Wanita, Bayi, Dan Keluarga. Volume 2. Edisi 18. Jakarta: EGC.

Rekam Medik RSUD Prof. Dr. Margono Soekardjo. (2013) Purwokerto.

Rekam Medik RSUD Prof. Dr. Margono Soekardjo. (2014) Purwokerto.

Saryono. (2008). Metodologi Penelitian Kesehatan Penuntun Praktis Bagi Pemula. Jogjakarta: Mitra Cendikia Press.

Sudijono. (2009). Pengantar Statistik Pendidikan. Jakarta: Rajawali Pres.

Tarigan. (2009). Sehat Dengan Terapi Pijat. Diakses 18 November 2013 dari http://puregan.indonetwork.co.id/1453065 Jam 14.08 WIB

Wiknjosastro, Hanifa. (2007). Ilmu Bedah Kebidanan. Jakarta: Yayasan Bina Pustaka Sarwono Prawirohardjo.

Wijiyanti, Fajar (2010) Efektivitas Terapi Spiritual Emotional Freedom 
Atun Raudotul : The Effectiveness of Fingerhold Relaxation Technique

Technique (SEFT) terhadap Penurunan Intensitas Nyeri pada Pasien Paska-operasi Sectio Caesaria. Undergraduate thesis, Universitas Diponegoro

Yuliatun, Laily. (2008). Penanganan Nyeri Persalinan Dengan Metode Nonfarmakologi. JawaTimur: Bayumedia Publishing.

Yuniarsih SM. 2012. Pengaruh SEFT untuk mengurangi nyeri dan kecemasan pada ibu Bersalin Kala I. Pekalongan. Tesis

Zainuddin, Ahmad Faiz. Spiritual Emosional Freedom Technique (SEFT). Jakarta: Afzan Publishing. 2012; 3-65.

Zakiyyah M. 2010. Pengaruh Terapi Spiritual Emosional Freedom Technique (SEFT) Terhadap Penanganan Nyeri Dismenorea. Probolinggo. Tesis.

Zees, RF. (2012). Pengaruh Tehnik Relaksasi Terhadap Respon Adaptasi Nyeri Pada Pasien Apendektomi Di Ruang G2 Lantai II Kelas III Blud Rsu Prof. Dr. H. Aloei Saboe Kota Gorontalo. Diakses $27 \quad$ Oktober 2013 dari https://www.google.co.id/\#q=Pengaruh+Tehnik+Relaksasi+Terhadap+Respon+A daptasi+Nyeri+Pada+Pasien+Apendektomi+Di+Ruang+G2+Lantai+II+Kelas+III +Blud+Rsu+Prof.+Dr.+H.+Aloei+Saboe+Kota+Gorontalo Jam 09.02 WIB 